\title{
Three-year evaluation of the nosocomial infections in pediatrics: bacterial and fungal profile and antimicrobial resistance pattern
}

\author{
Mehrnoush Afsharipour ${ }^{1}$, Shima Mahmoudi ${ }^{1,2}$, Hojatollahh Raji ${ }^{3}$, Babak Pourakbari ${ }^{1} 2^{*}$ and Setareh Mamishi ${ }^{2,4^{*}}$
}

\begin{abstract}
Background: Nosocomial infections (NIs) could lead to considerably higher mortality rates, length of the hospital stays and costs, and represent a serious public health concern worldwide. Besides, the unreasonable use of antibiotics could lead to get resistant to different antibiotics and create limited therapeutic options, increased risks of treatment failure and poor patient management. The current study aimed to evaluate the prevalence and antimicrobial susceptibility of NIs in an Iranian referral pediatrics hospital during 3 years.

Methods: During the 3-year period, all electronic medical records of nosocomial infection episodes in hospitalized patients were retrospectively reviewed. The bacterial and fungal profile and antimicrobial susceptibility profiles of isolates recovered from different samples of patients with NIs were determined.

Results: In this study, a total of 718 patients with NIs was found, among which $61.3 \%$ were male $(N=440)$. The median age of the patients was 2.5 years (IQR: 1 month to 3 years). Klebsiella pneumonia and Candida spp. isolates were the most prevalent microorganisms ( $N=125,17.4 \%, N=121,16.9 \%$, respectively), followed by Pseudomonas aeruginosa $(N=72,10 \%)$ and Coagulase-negative Staphylococci (CoNS) $(N=69,9.6 \%)$. Pseudomonas aeroginusa strains showed high sensitivity to the studied antibiotics. Acinetobacter baumannii strains displayed more than $90 \%$ resistance to the almost all antibiotics. All of the tested isolates of $S$. maltophilia were susceptible to Trimethoprim-sulfamethoxazole (100\%) and showed high susceptibility rate to ciprofloxacin (96.4\%). Vancomycin resistance was not reported in S. aureus isolates, while 64\% of Enterococcus spp. was resistant to vancomycin. The rates of methicillin resistance for S. aureus and CoNS isolates were $45.5 \%$ and $85.7 \%$, respectively.
\end{abstract}

Conclusions: High frequency of antimicrobial resistance to the commonly tested antibiotics is a concerning alarm. Therefore, effective infection control programs and rational antibiotic use policies should be established promptly.

Keywords: Nosocomial infections, Antimicrobial susceptibility, Pediatrics

*Correspondence: pourakbari@sina.tums.ac.ir; smamishi@sina.tums.ac.ir

2 Pediatric Infectious Disease Research Center, Tehran University

of Medical Sciences, Tehran, Iran

${ }^{4}$ Pediatric Infectious Disease Research Center, Pediatrics Center of Excellence, Children's Medical Center Hospital, Dr. Gharib Street, Keshavarz Boulevard, Tehran, Iran

Full list of author information is available at the end of the article

\section{Introduction}

A nosocomial infection (NI) (also known as hospitalacquired infection) is a localized or a systemic infection occurring with an adverse reaction to infectious agents that develops in $48 \mathrm{~h}$ or more after admission [1]. NIs could lead to considerably higher mortality rates, length of the hospital stay and costs, and represent a serious public health concern worldwide [2,3]. The leading bacteria related to NIs are Staphylococcus aureus, coagulase-negative staphylococci (CoNS), Streptococcus original author(s) and the source, provide a link to the Creative Commons licence, and indicate if changes were made. The images or other third party material in this article are included in the article's Creative Commons licence, unless indicated otherwise in a credit line to the material. If material is not included in the article's Creative Commons licence and your intended use is not permitted by statutory regulation or exceeds the permitted use, you will need to obtain permission directly from the copyright holder. To view a copy of this licence, visit http://creativecommons.org/licenses/by/4.0/. The Creative Commons Public Domain Dedication waiver (http://creativeco mmons.org/publicdomain/zero/1.0/) applies to the data made available in this article, unless otherwise stated in a credit line to the data. 
pneumoniae, Escherichia coli, Pseudomonas aeruginosa, Haemophilus influenzae, Klebsiella pneumoniae, Acinetobacter, and Enterococci $[4,5]$.

Nowadays, antibiotics remain the leading therapy for treating bacterial infections. However, by the unreasonable use of antibiotics, certain strains of multidrug-resistant (MDR) bacteria have emerged by selection pressure; consequently, bacteria that have been once sensitive, reemerged as resistant to different antibiotics and create limited therapeutic options, increased risks of treatment failure and poor patient management [6]. Knowledge of proper antimicrobial prescription policy of a particular setting in addition to the investigation of causative agents and their antimicrobial susceptibility profile, is essential to improve the management and reduction of the rate of NIs [7]. The aim of the current study was the evaluation of the frequency and antimicrobial susceptibility of NIs in an Iranian children medical center during three years.

\section{Materials and methods}

This cross-sectional study was carried out in the referral hospital of Children's Medical Center, Tehran, Iran between March 2017 and February 2020. Ethical approval (IR.TUMS.CHMC.REC.1399.037) was obtained from the Ethical Committee of Tehran University of Medical Sciences, Tehran, Iran.

All patients who admitted to the medical wards of Children's Medical Center, Tehran, Iran for more than $48 \mathrm{~h}$ and had the evidence of NIs with positive blood, wounds and sterile fluids culture of gram-positive/gram-negative bacteria and fungi were included in this study. Duplicate isolates from one patient were excluded from the study. In vitro phenotypic characterization of bacteria or fungi was carried out using standard culture and biochemical tests as described previously [8]. The disk diffusion method or minimal inhibitory concentration (MIC) was used to test each isolate for in vitro antimicrobial susceptibility based on the Clinical and Laboratory Standards Institute criteria [9].

The following antibiotics disks from MAST Categories Ltd., Merseyside, UK, were used: imipenem $(10 \mu \mathrm{g})$, ampicillin $(10 \mu \mathrm{g})$, cefotaxime $(30 \mu \mathrm{g})$, clindamycin $(2 \mu \mathrm{g})$, Trimethoprim-sulfamethoxazole $(1.25 / 23.75 \mathrm{mg})$, ceftazidime $(30 \mu \mathrm{g})$, nitrofurantoin $(200 \mu \mathrm{g})$, ceftriaxone $(30 \mu \mathrm{g})$, erythromycin $(15 \mu \mathrm{g})$, gentamycin $(10 \mu \mathrm{g})$, cefepime $(30 \mu \mathrm{g})$, penicillin $(10 \mu \mathrm{g})$, linezolid $(30 \mu \mathrm{g})$, cefoxitin $(30 \mu \mathrm{g})$. Staphylococcus aureus ATCC 25,923 was used for quality control of the test. The MICs of vancomycin and colistin were determined by E-test methods.

Statistical analysis of the results was performed using SPSS 13.0 (SPSS Inc. Chicago, IL, USA). The results were presented as mean, frequency and standard deviation for quantitative and percentage and frequency for qualitative data.

\section{Results}

In the current study, a total of 718 patients included, among which $61.3 \%$ were male $(\mathrm{N}=440)$. The median age of the patients was 2.5 years (IQR: 1 month-3 years). Among the patients, 27.2\% had underlying heart disease $(\mathrm{N}=195)$ and $16.3 \%$ had seizures $(\mathrm{N}=117)$. Intrinsic and acquired immunodeficiency was also reported in a number of patients $(\mathrm{N}=35,4.9 \%, \mathrm{~N}=59,8.2 \%$, respectively). Three hundred and eighty-four patients (53.5\%) utilized catheters, and 101 of them (14.1\%) had endotracheal tube during their hospitalization.

The frequency of isolated microorganisms among the studied patients based on the sources of their isolation was mentioned in Table 1. Klebsiella pneumonia and Candida spp. were the most prevalent isolates $(\mathrm{N}=125$, $17.4 \%, \mathrm{~N}=121,16.9 \%$, respectively), followed by $P$. aeruginosa $(\mathrm{N}=72,10 \%)$ and CoNS $(\mathrm{N}=69,9.6 \%)$. Also, most of the samples were isolated from blood $(\mathrm{N}=495$, $69 \%)$, followed by sterile fluids $(\mathrm{N}=165,23 \%)$ and finally wounds $(\mathrm{N}=58,8 \%)$. Klebsiella pneumonia was the most frequent organism isolated from blood and wounds, and Candida spp. was the most frequent organism isolated from sterile fluids.

There was a slight decrease in the total number of isolates each year compared to the previous year (the first year: 272 patients, $37.9 \%$; the second year: 234 patients, 32.6\%; the third year: 212 patients, 29.5\%). Morganella morganii and Haemophilus spp. specimens were isolated only in the first year of the study (2017). During these years, Serratia marcescens $(n=13, n=12, n=6$, respectively) and $S$. aureus $(\mathrm{n}=19, \mathrm{n}=10, \mathrm{n}=6$, respectively) showed a decreasing trend. While the Enterococcus spp. $(\mathrm{n}=21, \mathrm{n}=13, \mathrm{n}=13$, respectively) and $P$. aeruginosa $(\mathrm{n}=30, \mathrm{n}=21, \mathrm{n}=21$, respectively) after a 2 -year downward trend, in 2019, remained stable. The frequency of Pseudomonas spp. $(\mathrm{n}=6, \mathrm{n}=17, \mathrm{n}=25$, respectively) and Enterobacter spp. $(\mathrm{n}=5, \mathrm{n}=16, \mathrm{n}=17$, respectively) represented an increasing trend.

Most of the isolates were collected from hospitalized patients at neonatal intensive care unit (NICU) and pediatric intensive care unit (PICU) $(\mathrm{N}=109,15.2 \%, \mathrm{~N}=100$, $13.9 \%$, respectively) and the most isolated microorganisms from them were $K$. pneumonia $(\mathrm{N}=29,26.6 \%)$ and Candida spp. $(\mathrm{N}=25,25 \%)$, respectively.

Antibiotic susceptibility frequencies of evaluated microorganisms were depicted in Table 2. Escherichia coli, Acinetobacter baumannii, S. marcescens, K. pneumonia and Pseudomonas spp. strains showed $100 \%$ sensitivity to colistin. Pseudomonas aeroginusa strains as a whole showed significant sensitivity to the studied and 
Table 1 The frequency of isolated microorganisms among the studied patients

\begin{tabular}{|c|c|c|c|c|}
\hline Bacteria & Blood [N (\%)] & Sterile fluids [N (\%)] & Wound [N (\%)] & Total [N (\%)] \\
\hline K.pneumonia & $84(16.9)$ & $26(15.8)$ & $15(25.9)$ & $125(17.4)$ \\
\hline Candida spp. & $81(16.4)$ & $34(20.6)$ & $6(10.3)$ & $121(16.9)$ \\
\hline P. aureoginosa & $39(7.9)$ & $24(14.5)$ & $9(15.5)$ & $72(10)$ \\
\hline CONS & $62(12.5)$ & $4(2.42)$ & $3(5.2)$ & $69(9.6)$ \\
\hline Acinetobacter baumannii & $18(3.6)$ & $29(17.6)$ & $4(6.9)$ & $51(7.1)$ \\
\hline Psuedomonas spp. & $39(7.9)$ & $9(5.45)$ & 0 & $48(6.7)$ \\
\hline Enterococcus spp. & $39(7.9)$ & $2(1.21)$ & $6(10.3)$ & $47(6.5)$ \\
\hline E. coli & $25(5)$ & $9(5.45)$ & $7(12.1)$ & $41(5.7)$ \\
\hline S. aureus & $28(5.7)$ & $3(1.82)$ & $4(6.9)$ & $35(4.9)$ \\
\hline Serratia marcescens & $24(4.8)$ & $5(3.03)$ & $2(3.4)$ & $31(4.3)$ \\
\hline Stenotrophomonas maltophilia & $24(4.8)$ & $6(3.6)$ & $1(1.72)$ & $31(4.3)$ \\
\hline Enterobacter spp. & $19(3.8)$ & $8(4.8)$ & $1(1.72)$ & $28(3.9)$ \\
\hline Streptococcus spp. & $6(1.2)$ & $2(1.2)$ & 0 & $8(1.1)$ \\
\hline Burkholderia cepacia & $3(0.6)$ & $3(1.8)$ & 0 & $6(0.8)$ \\
\hline Morganella morganii & $2(0.4)$ & 0 & 0 & $2(0.3)$ \\
\hline Aspergilus spp. & 0 & $1(0.6)$ & 0 & $1(0.1)$ \\
\hline Salmonella spp. & $1(0.2)$ & 0 & 0 & $1(0.1)$ \\
\hline Haemophilus spp. & $1(0.2)$ & 0 & 0 & $1(0.1)$ \\
\hline Total & $495(100)$ & $165(100)$ & $58(100)$ & $718(100)$ \\
\hline
\end{tabular}

the most sensitive antibiotics were imipenem (80.4\%) and ceftazidime (80.8\%). Subsequently, the highest sensitivity to ceftazidime was observed in Pseudomonas spp. (79.2\%), while A. baumannii strains showed $94.8 \%$ resistance to this antibiotic.

Vancomycin resistance was not reported among $S$. aureus isolates in this study. Clindamycin had the least effect on CoNS strains (18.6\%). Staphylococcus aureus strains were highly resistant to gentamycin (100\%), ciprofloxacin (100\%) and penicillin (85.7\%). Methicillinresistant S. aureus (MRSA) was found in $45.5 \%$ of the isolates. However, next to vancomycin, nitrofourantoin and imipenem (each $\mathrm{n}=1 / 1,100 \%$ ), and Trimethoprim-sulfamethoxazole $(n=18 / 23,78.3)$ were the most effective antimicrobial agents on it.

High levels of resistance to gentamycin were also showed among $S$. marcescens $(\mathrm{n}=19 / 22,86.4 \%)$, Enterococcus spp. $(\mathrm{n}=13 / 17,76.5 \%)$, A. baumannii $(\mathrm{n}=29 / 38), 76.3 \%)$, and Pseudomonas spp. $(\mathrm{n}=16 / 21,76.2 \%)$ strains.

All of the tested isolates of Streptococcus spp. were $100 \%$ sensitive to ampicillin and penicillin (each $n=3 / 3$ ), and vancomycin $(n=4 / 4)$, but fully resistant to erythromycin $(\mathrm{n}=2 / 2)$ and Trimethoprim-sulfamethoxazole $(\mathrm{n}=1 / 1)$.

Escherichia coli showed a high level of resistance to cefotaxime $(\mathrm{n}=28 / 33,87.5 \%)$, Trimethoprim-sulfamethoxazole $(n=25 / 30,83.3 \%)$, cefepime $(n=23 / 28,82.2 \%)$, and imipenem $(\mathrm{n}=7 / 9,77.8 \%)$, but $100 \%$ sensitivity to nitrofourantoin $(\mathrm{n}=14 / 14)$.
Acinetobacter baumannii strains also displayed more than $90 \%$ resistance to the almost all antibiotics studied including imipenem, cefepime, Trimethoprim-sulfamethoxazole, meropenem, piperacillin/ tazobactam, amikacin, ciprofloxacin, and cefotaxime. Likewise, K. pneumonia $(n=64 / 84$, $76.2 \%)$ and $S$. marcescens $(n=18 / 20,90 \%)$ strains were resistant to piperacillin/tazobactam. However, this antibiotic was mostly effective on Pseudomonas spp. ( $\mathrm{n}=18 / 20,90 \%)$.

All of the tested isolates of $S$. maltophilia were susceptible to Trimethoprim-sulfamethoxazole $(n=29 / 29$, $100 \%)$ and showed high susceptibility rate to ciprofloxacin $(n=27 / 28,96.4 \%)$. The isolates of Enterobacter spp. showed $73.7 \%$ sensitivity to amikacin $(n=14 / 19)$.

\section{Discussion}

In this study, we evaluated the microorganisms isolated from NIs over three consecutive years which generally had a slow decreasing trend.

The present study showed $K$. pneumoniae $(\mathrm{N}=125$, $17.4 \%)$, Candida spp. ( $\mathrm{N}=121,16.9 \%)$, and P. aeruginosa $(\mathrm{N}=72,10 \%)$ as the most frequent microorganisms which cause NIs among the studied children. Of course other frequent NI-causing bacteria were reported in our study including CoNS (9.6\%), A. baumannii (7.1\%), Psuedomonas spp. (6.7\%), and Enterococcus spp. (6.5\%). 61\% of isolated organisms were gram-negative bacteria, which was about three times more than the number of grampositive bacteria isolated in our study (22.1\%). 
Table 2 The percentage of antimicrobial susceptibility of NIs in an Iranian referral pediatrics hospital

\begin{tabular}{|c|c|c|c|c|c|c|c|c|c|c|}
\hline Bacteria & \multicolumn{2}{|c|}{ Gentamycin } & $\begin{array}{l}\text { Trimethoprim } \\
\text { sulfamethoxazole }\end{array}$ & Imipenem & Nitrofourantoin & Cefotaxime & Clindamycin & Ampicillin & Ceftazidim & Penicillin \\
\hline E. coli & \multicolumn{2}{|c|}{$58.6 \%$} & $16.7 \%$ & $22.2 \%$ & $100 \%$ & $12.5 \%$ & - & $0 \%$ & $33.3 \%$ & $22.7 \%$ \\
\hline $\begin{array}{l}\text { Enterococ- } \\
\text { cus spp. }\end{array}$ & \multicolumn{2}{|c|}{$23.5 \%$} & $100 \%$ & $50 \%$ & $88.9 \%$ & $0 \%$ & $0 \%$ & $26.9 \%$ & - & - \\
\hline $\begin{array}{l}\text { Psue- } \\
\text { domonas } \\
\text { spp. }\end{array}$ & \multicolumn{2}{|c|}{$23.8 \%$} & - & $84.2 \%$ & - & - & - & - & $79.2 \%$ & - \\
\hline $\begin{array}{l}\text { P. aureogi- } \\
\text { nosa }\end{array}$ & \multicolumn{2}{|c|}{$72.7 \%$} & $75 \%$ & $80.4 \%$ & - & $62.5 \%$ & - & - & $80.8 \%$ & - \\
\hline $\begin{array}{l}\text { K.pneumo- } \\
\text { nia }\end{array}$ & \multicolumn{2}{|c|}{$37.5 \%$} & $37.2 \%$ & $52.9 \%$ & $33.3 \%$ & $4.4 \%$ & $100 \%$ & $100 \%$ & $100 \%$ & - \\
\hline CONS & \multicolumn{2}{|l|}{$0 \%$} & $35.4 \%$ & - & $50 \%$ & $0 \%$ & $18.6 \%$ & $0 \%$ & - & $0 \%$ \\
\hline S. aureus & \multicolumn{2}{|l|}{$0 \%$} & $78.3 \%$ & $100 \%$ & $100 \%$ & - & $45.5 \%$ & - & - & $14.3 \%$ \\
\hline $\begin{array}{l}\text { Enterobac- } \\
\text { terspp. }\end{array}$ & \multicolumn{2}{|c|}{$50 \%$} & $36.4 \%$ & $100 \%$ & $0 \%$ & $14.3 \%$ & - & $0 \%$ & $100 \%$ & $0 \%$ \\
\hline $\begin{array}{l}\text { Acineto- } \\
\text { bacter } \\
\text { baumannii }\end{array}$ & \multicolumn{2}{|c|}{$23.7 \%$} & $9.4 \%$ & $5.3 \%$ & - & $2.4 \%$ & - & $16.7 \%$ & $5.3 \%$ & - \\
\hline $\begin{array}{l}\text { Serratia } \\
\text { marces- } \\
\text { cens }\end{array}$ & \multicolumn{2}{|c|}{$13.6 \%$} & $100 \%$ & $100 \%$ & - & $16 \%$ & - & - & $100 \%$ & - \\
\hline $\begin{array}{l}\text { Steno- } \\
\text { tropho- } \\
\text { monas } \\
\text { maltophilia }\end{array}$ & \multicolumn{2}{|l|}{$0 \%$} & $100 \%$ & $0 \%$ & - & - & - & - & - & $0 \%$ \\
\hline $\begin{array}{l}\text { Candida } \\
\text { spp. }\end{array}$ & \multicolumn{2}{|l|}{-} & - & - & - & - & - & - & - & \\
\hline $\begin{array}{l}\text { Streptococ- } \\
\text { cus spp. }\end{array}$ & \multicolumn{2}{|l|}{-} & $0 \%$ & - & - & - & $50 \%$ & $100 \%$ & - & $100 \%$ \\
\hline $\begin{array}{l}\text { Burkholde- } \\
\text { ria cepacia }\end{array}$ & 33.39 & 10 & & $33.3 \%$ & $0 \%$ & $100 \%$ & - & $0 \%$ & $66.7 \%$ & - \\
\hline $\begin{array}{l}\text { Morganella } \\
\text { morganii }\end{array}$ & $50 \%$ & 10 & & - & - & $100 \%$ & - & - & - & - \\
\hline Total & 41.19 & & & $59.4 \%$ & $63.8 \%$ & $10.1 \%$ & $29.6 \%$ & $29.5 \%$ & $56.5 \%$ & $12.6 \%$ \\
\hline Bacteria & & Vancomycin & Colistin & Methicillin & Erythromycin & Ciprofloxacin & Tazocin & Linezolide & Amikacin & Cefepime \\
\hline E. coli & & - & $100 \%$ & - & - & $50.00 \%$ & $59.3 \%$ & - & $78.1 \%$ & $17.9 \%$ \\
\hline $\begin{array}{l}\text { Enterococcu } \\
\text { spp. }\end{array}$ & & $36 \%$ & - & - & $0 \%$ & $0 \%$ & $40 \%$ & $100 \%$ & $60 \%$ & $66.7 \%$ \\
\hline $\begin{array}{l}\text { Psuedomon } \\
\text { spp. }\end{array}$ & & - & $100 \%$ & - & - & $100 \%$ & $90 \%$ & - & $34.8 \%$ & $50 \%$ \\
\hline P. aureogino & & $100 \%$ & $50 \%$ & - & - & $75 \%$ & $78.4 \%$ & - & $81.8 \%$ & $62 \%$ \\
\hline K.pneumon & & $100 \%$ & $100 \%$ & - & - & $55.6 \%$ & $23.8 \%$ & - & $25.5 \%$ & $11.5 \%$ \\
\hline CONS & & $100 \%$ & - & $14.3 \%$ & $4.5 \%$ & - & $100 \%$ & - & $50 \%$ & - \\
\hline S. aureus & & $100 \%$ & - & $54.5 \%$ & $35 \%$ & $0 \%$ & - & - & - & - \\
\hline $\begin{array}{l}\text { Enterobacte } \\
\text { spp. }\end{array}$ & & $0.00 \%$ & - & - & - & $33.3 \%$ & $68.4 \%$ & $100 \%$ & $73.7 \%$ & $47.1 \%$ \\
\hline $\begin{array}{l}\text { Acinetobact } \\
\text { baumannii }\end{array}$ & & - & $100 \%$ & - & - & $10 \%$ & $9.4 \%$ & - & $9.8 \%$ & $5.6 \%$ \\
\hline $\begin{array}{l}\text { Serratiama } \\
\text { escens }\end{array}$ & & - & $100 \%$ & - & - & $33.3 \%$ & $10 \%$ & - & $24 \%$ & $0 \%$ \\
\hline $\begin{array}{l}\text { Stenotropho } \\
\text { monas malt } \\
\text { ophilia }\end{array}$ & & - & - & - & $100 \%$ & $96.4 \%$ & - & - & $0 \%$ & - \\
\hline Candida sp & & $100 \%$ & - & - & - & - & - & - & - & - \\
\hline $\begin{array}{l}\text { Streptococc } \\
\text { spp. }\end{array}$ & & $100 \%$ & - & - & $0 \%$ & - & - & - & - & - \\
\hline
\end{tabular}


Table 2 (continued)

\begin{tabular}{|c|c|c|c|c|c|c|c|c|c|}
\hline Bacteria & Vancomycin & Colistin & Methicillin & Erythromycin & Ciprofloxacin & Tazocin & Linezolide & Amikacin & Cefepime \\
\hline $\begin{array}{l}\text { Burkholderia } \\
\text { cepacia }\end{array}$ & - & $0 \%$ & - & - & $50 \%$ & $66.7 \%$ & - & $0 \%$ & $0 \%$ \\
\hline $\begin{array}{l}\text { Morganella } \\
\text { morganii }\end{array}$ & - & - & - & - & - & $100 \%$ & $100 \%$ & $100 \%$ & $100 \%$ \\
\hline Total & $85.2 \%$ & $96.9 \%$ & $28.1 \%$ & $14.7 \%$ & $49.4 \%$ & $44.8 \%$ & $100 \%$ & $43.0 \%$ & $26.8 \%$ \\
\hline
\end{tabular}

Likewise, high rate of gram-negative bacteria was reported in Feleke et al. (53.2\%) study [6]. Also unlike the study of Feleke et al. and the one reported from Jimma which mentioned $S$. aureus and $E$. coli as their the most common isolates $[6,10]$, in the present study, K. pneumoniae was the most common bacteria isolated. Similarly, in the study accomplished by Mahmoudi et al., [14] K. pneumoniae $(\mathrm{n}=263,27.5 \%)$ was reported as the most frequent bacteria. In a study by Bouza et al. [11], E. coli (35.3\%) was the most commonly isolated microorganism, and Klebsiella spp. were reported as $9.8 \%$ of the pathogens. Gupta et al. [12] reported that S. aureus and CoNS as the most common isolated gram-positive bacteria which is in line with our results. Nouri et al. reported the high prevalence of gram-negative bacteria (77.9\%) in NIs and low prevalence of gram-positive bacteria (22.1\%), exactly as ours, and the most common bacterium causing NIs among the latter was $S$. aureus [13].

$67 \%$ of isolated strains was from ICUs (mostly NICU and PICU) $(\mathrm{N}=482)$, which was compatible with the results of our previous study [14]. Also, Alvares et al. reported nosocomial pneumonia as the third most common NI in their pediatric intensive care unit [2]. Candida spp. strains were isolated frequently from PICU (25\%) and emergency ICU (24.4\%). Surgical and ICU patients are at higher risk of rising nosocomial fungal infections [15]. In critically ill patients, the disseminated candida infections are the principal causes of morbidity and mortality both in immunocompetent and immunocompromised patients [16].

A. baumannii strains were considerably resistant to almost all tested antibiotics except for colistin $(100 \%$ sensitivity), which is similar to previous studies $[17,18]$. Sohail et al. [19] also showed that only $0.1 \%$ of the isolated strains were resistant to colistin. The results of study reported by Vahdani et al. [20] showed antibioticresistant $A$. Baumannii infections with high resistant rate to ceftazidime (96\%), followed by ceftizoxime (95\%), ceftriaxone (93\%), ciprofloxacin (85\%), and trimethoprim/ sulfamethoxazole $(85 \%)$. Along with the significance of MDR A. baumannii in NIs, the increasing reports of outbreaks caused by carbapenem-resistant $A$. baumannii in recent years have become another frightening reality [21].
In the present study, K. pneumonia strains were highly resistant to cefotaxime (95.6\%), while showed $100 \%$ susceptibility to colistin, vancomycin, ampicillin, ceftazidime and clindamycin. Sensitivity to gentamycin reported as low as $37.5 \%$ among $K$. pneumonia strains in our study. Compared with the results of the study by Ares et al. [22], the resistance rates of isolates in the current study against studied antibiotics, especially carbapenems, were considerably high. This difference in the resistance patterns of $K$. pneumoniae could be due to the different prevalent clones in Iran and other countries in addition to differences in antibiotic treatment regimens in different areas [23].

All E. coli isolates tested in this study were sensitive to nitrofurantoin and colistin, while showing significant resistance to the other antibiotics compared to our previous study [17]. However, the resistance of this microorganism to imipenem (77.8\% in comparison with $8 \%$ ) has increased significantly compared to the mentioned study. High resistance to ampicillin has been reported in other studies, as well [24-26].

The frequency of MRSA (43\%) was more than the amount reported by our previous study (26\%) [27], Nigussie et al. and Latif et al. (38.5\% and 31.25\%, respectively) $[28,29]$.

In this study, $P$. aeruginosa strains were highly sensitive to amikacin (81.8\%), imipenem (80.4\%), piperacillin/ tazobactam (78.4\%), Trimethoprim-sulfamethoxazole and ciprofloxacin (75\%). However, resistance rates of $P$. aeruginosa to gentamicin (27.3\%), amikacin (18.2\%) and ceftazidime (19.2\%) were higher than our recent study [14]. In addition, lower resistance rate for cefepime was reported by Larru et al. (4.3\%) [30] and Ares et al. (8.5\%) [22], compared to the percentage of $38 \%$ in the current study.

There are only a limited number of studies describing the S. maltophilia infection in children [31]. Treatment of nosocomial S. maltophilia infections is complicated due to high rates of antibiotic resistance [32]. We reported $100 \%$ resistant S. maltophilia isolate to gentamycin, imipenem, and penicillin $(n=1 / 1)$. However, treatment of $S$. maltophilia infection is difficult due to antimicrobial resistance to a variety of agents; trimethoprimsulfamethoxazol can continue to be the first choice for 
the treatment of S. maltophilia. In the study performed by Alsuhaibani et al., [33] the most effective antibiotic against S. maltophilia isolates was Trimethoprim-sulfamethoxazole (94.1\%), which is consistent with our data $(100 \%)$. Also in the study by Sun et al. [32], the resistance rate of $S$. maltophilia strains to cefpime, cefotaxime, ceftazidime and gentamicin was $45.1 \%, 94.1 \%, 60.8 \%$ and $82.4 \%$, respectively.

Regarding the frequency of resistance to vancomycin, no cases were reported among S. aureus, while $64 \%$ of Enterococcus spp. were resistant to vancomycin that is similar to our recent previous study [27] and is higher than our previous studies in our hospital during 20092010 [34]. Since NIs are an important determinant in hospital, improving of the prevention and treatment of NIs is still highly needed [7].

\section{Conclusions}

High frequency of antimicrobial resistance to the commonly tested antibiotics is a concerning alarm. Therefore, effective infection control programs and rational antibiotic use policies should be established promptly.

\section{Abbreviations \\ NIs: Nosocomial infections; CoNS: Coagulase-negative staphylococci; MDR: Multidrug-resistant; MIC: Minimal inhibitory concentration; NICU: Neonatal intensive care unit; PICU: Pediatric intensive care unit.}

\section{Acknowledgements}

This study was postgraduate thesis of Dr. Mehrnoush Afsharipour.

\section{Authors' contributions}

MA and HR contributed to data acquisition and data interpretation. ShM contributed to the statistical analysis and writing of the manuscript. BP and SeM revised the manuscript. All authors read and approved the final manuscript.

\section{Funding}

No funding was available.

\section{Availability of data and materials}

All data obtained.

\section{Declarations}

Ethics approval and consent to participate

Ethical approval (IR.TUMS.CHMC.REC.1399.037) was obtained from the Ethical Committee of Tehran University of Medical Sciences, Tehran, Iran.

\section{Consent for publication}

Not applicable.

\section{Competing interests}

The authors declare that they have no competing interests.

\section{Author details}

${ }^{1}$ Pediatrics Center of Excellence, Children's Medical Center, Tehran University of Medical Sciences, Tehran, Iran. ${ }^{2}$ Pediatric Infectious Disease Research Center, Tehran University of Medical Sciences, Tehran, Iran. ${ }^{3}$ Department of Pediatric Surgery, Pediatrics Center of Excellence, Children's Medical Center, Tehran University of Medical Sciences, Tehran, Iran. ${ }^{4}$ Pediatric Infectious Disease Research
Center, Pediatrics Center of Excellence, Children's Medical Center Hospital, Dr. Gharib Street, Keshavarz Boulevard, Tehran, Iran.

Received: 3 March 2021 Accepted: 31 January 2022

Published online: 16 February 2022

\section{References}

1. Tolera M, Abate D, Dheresa M, Marami D. Bacterial nosocomial infections and antimicrobial susceptibility pattern among patients admitted at Hiwot Fana Specialized University Hospital, Eastern Ethiopia. Adv Med. 2018. https://doi.org/10.1155/2018/2127814.

2. Alvares PA, Arnoni MV, da Silva CB, Sáfadi MAP, Mimica MJ. Hospitalacquired infections in children: a Latin American Tertiary teaching hospital 5-year experience. Pediatr Infect Dis J. 2019;38(1):e12-4.

3. Khazaei S, Khazaei S, Ayubi E. Importance of prevention and control of nosocomial infections in Iran. Iran J Public Health. 2018;47(2):307-8.

4. Davoudi AR, Najafi N, Shirazi MH, Ahangarkani F. Frequency of bacterial agents isolated from patients with nosocomial infection in teaching hospitals of Mazandaran University of Medical Sciences in 2012. Caspian J Intern Med. 2014;5(4):227.

5. Siddique T, Farzand S, Waheed SS, Khan F. Frequency and etiology of nosocomial infections in medical unit-I, Nawaz Sharif Social Security teaching hospital, Lahore. Pak J Med Sci. 2012;6(2):499-501.

6. Feleke T, Eshetie S, Dagnew M, Endris M, Abebe W, Tiruneh M, et al. Multidrug-resistant bacterial isolates from patients suspected of nosocomial infections at the University of Gondar Comprehensive Specialized Hospital, Northwest Ethiopia. BMC Res Notes. 2018;11(1):1-7.

7. Mamishi S, Pourakbari B, Teymuri M, Babamahmoodi A, Mahmoudi S. Management of hospital infection control in Iran: a need for implementation of multidisciplinary approach. Osong Public Health Res Perspect. 2014;5(4):179-86

8. Cheesbrough M. District laboratory practice in tropical countries, part 2. Cambridge: Cambridge University Press; 2005

9. Bayer A, Kirby W, Sherris J, Turck M. Antibiotic susceptibility testing by a standardized single disc method. Am J clin pathol. 1966;45(4):493-6.

10. Mama M, Abdissa A, Sewunet T. Antimicrobial susceptibility pattern of bacterial isolates from wound infection and their sensitivity to alternative topical agents at Jimma University Specialized Hospital, south-west Ethiopia. Ann Clin Microbiol Antimicrob. 2014;13(1):1-10.

11. Bouza E, San Juan R, Munoz P, Voss A, Kluytmans J, Infections C-oGotESGoN. A European perspective on nosocomial urinary tract infections II. Report on incidence, clinical characteristics and outcome (ESGINI-04 study). Clin Microbiol Infect. 2001;7(10):532-42.

12. Gupta R, Malik A, Rizvi M, Ahmed M, Hashmi A. Multidrug resistant Gram positive pathogens with special reference to MRSA and biofilm production in ICU patients: recurrent challenge for clinicians. Int J Curr Microbiol App Sci. 2015;1:207-12.

13. Nouri F, Karami P, Zarei O, Kosari F, Alikhani MY, Zandkarimi E, et al. Prevalence of common nosocomial infections and evaluation of antibiotic resistance patterns in patients with secondary infections in Hamadan, Iran. Infect Drug Resist. 2020;13:2365.

14. Mamishi S, Mahmoudi S, Naserzadeh N, Sadeghi RH, Ashtiani MTH, Bahador A, et al. Antibiotic resistance and genotyping of gram-negative bacteria causing hospital-acquired infection in patients referred to Children's Medical Center. Infect Drug Resist. 2019;12:3377.

15. Jahagirdar VL, Davane MS, Aradhye SC, Nagoba BS. Candida species as potential nosocomial pathogens-a review. Electron I Gen Med. 2018;15(2):em05.

16. Méan M, Marchetti O, Calandra T. Bench-to-bedside review: Candida infections in the intensive care unit. Crit Care. 2008;12(1):1-9.

17. Mahmoudi S, Mahzari M, Banar M, Pourakbari B, Ashtiani MTH, Mohammadi $M$, et al. Antimicrobial resistance patterns of Gram-negative bacteria isolated from bloodstream infections in an Iranian referral paediatric hospital: a 5.5-year study. J Glob Antimicrob Resist. 2017;11:17-22.

18. Pourakbari B, Mahmoudi S, Habibi R, Ashtiani MT, Sadeghi RH, Khodabandeh $\mathrm{M}$, et al. An increasing threat in an Iranian referral children's hospital: multidrug-resistant Acinetobacter baumannii. Infect Disord Drug Targets. 2018;18(2):129-35. 
19. Sohail M, Rashid A, Aslam B, Waseem M, Shahid M, Akram M, et al. Antimicrobial susceptibility of Acinetobacter clinical isolates and emerging antibiogram trends for nosocomial infection management. Rev Soc Bras Med Trop. 2016;49(3):300-4.

20. Vahdani P, Yaghoubi T, Aminzadeh Z. Hospital acquired antibiotic-resistant Acinetobacter baumannii infections in a 400-bed hospital in Tehran, Iran. Int J Prev Med. 2011;2(3):127.

21. Lin M-F, Lan C-Y. Antimicrobial resistance in Acinetobacter baumannii: from bench to bedside. World J Clin Cases. 2014;2(12):787.

22. Ares M, Alcántar-Curiel MD, Jiménez-Galicia C, Rios-Sarabia N, Pacheco S, De la Cruz M. Antibiotic resistance of gram-negative bacilli isolated from pediatric patients with nosocomial bloodstream infections in a Mexican tertiary care hospital. Chemotherapy. 2013;59(5):361-8.

23. Folgori L, Livadiotti S, Carletti M, Bielicki J, Pontrelli G, Degli Atti MLC, et al. Epidemiology and clinical outcomes of multidrug-resistant, gramnegative bloodstream infections in a European tertiary pediatric hospital during a 12-month period. Pediatr Infect Dis J. 2014;33(9):929-32.

24. Pourakbari B, Sadr A, Ashtiani MTH, Mamishi S, Dehghani M, Mahmoudi $S$, et al. Five-year evaluation of the antimicrobial susceptibility patterns of bacteria causing bloodstream infections in Iran. J Infect Dev Ctries. 2012;6(02):120-5.

25. Ashtiani MTH, Mamishi S, Masoomi A, Nasiri N, Hosseini M, Nikmanesh $B$, et al. Antimicrobial susceptibility associated with bloodstream infections in children: a referral hospital-based study. Braz J Infect Dis. 2013;17(4):497-9.

26. Ballot DE, Nana T, Sriruttan C, Cooper PA. Bacterial bloodstream infections in neonates in a developing country. ISRN Pediatr. 2012. https://doi.org/ 10.5402/2012/508512

27. Mamishi S, Mohammadian M, Pourakbari B, Sadeghi RH, Ashtiani MTH, Abdosalehi MR, et al. Antibiotic resistance and genotyping of grampositive bacteria causing hospital-acquired infection in patients referring to children's medical center. Infect Drug Resist. 2019;12:3719.

28. Negussie A, Mulugeta G, Bedru A, Ali I, Shimeles D, Lema T, et al. Bacteriological profile and antimicrobial susceptibility pattern of blood culture isolates among septicemia suspected children in selected hospitals Addis Ababa, Ethiopia. Int J Biolog Med Res. 2015;6(1):4709.

29. Latif S, Anwar MS, Ahmad I. Bacterial pathogens responsible for blood stream infection (BSI) and pattern of drug resistance in a tertiary care hospital of Lahore. Biomedica. 2009;25(2):101-5.

30. Larru B, Gong W, Vendetti N, Sullivan KV, Localio R, Zaoutis TE, et al. Bloodstream infections in hospitalized children: epidemiology and antimicrobial susceptibilities. Pediatr Infect Dis J. 2016;35(5):507-10.

31. Okba NM, Muller MA, Li W, Wang C, GeurtsvanKessel CH, Corman VM, et al. SARS-CoV-2 specific antibody responses in COVID-19 patients. Emerg Infect Dis. 2020. https://doi.org/10.3201/eid2607.200841.

32. Sun E, Liang G, Wang L, Wei W, Lei M, Song S, et al. Antimicrobial susceptibility of hospital acquired Stenotrophomonas maltophilia isolate biofilms. Braz J Infect Dis. 2016;20(4):365-73.

33. Alsuhaibani M, Aljarbou A, Althawadi S, Alsweed A, Al-Hajjar S. Stenotrophomonas maltophilia bacteremia in children: risk factors and mortality rate. Antimicrob Resist Infect Control. 2021;10(1):1-7.

34. Sabouni F, Movahedi Z, Mahmoudi S, Pourakbari B, Valian SK, Mamishi S. High frequency of vancomycin resistant Enterococcus faecalis in children: an alarming concern. J Prev Med Hyg. 2016;57(4):E201.

\section{Publisher's Note}

Springer Nature remains neutral with regard to jurisdictional claims in published maps and institutional affiliations.

Ready to submit your research? Choose BMC and benefit from:

- fast, convenient online submission

- thorough peer review by experienced researchers in your field

- rapid publication on acceptance

- support for research data, including large and complex data types

- gold Open Access which fosters wider collaboration and increased citations

- maximum visibility for your research: over $100 \mathrm{M}$ website views per year

At BMC, research is always in progress.

Learn more biomedcentral.com/submissions 